\title{
Radiolysis Studies of Oxidation and Nitration of Tyrosine and Some Other Biological Targets by Peroxynitrite-Derived Radicals
}

\author{
Lisa K. Folkes ${ }^{1}$, Silvina Bartesaghi ${ }^{2,3}{ }^{\mathbb{D}}$, Madia Trujillo ${ }^{2,3}$, Peter Wardman ${ }^{1}$ and Rafael Radi ${ }^{2,3, * \mathbb{C}}$ \\ 1 Formerly of the Gray Cancer Institute and MRC Oxford Institute for Radiation Oncology, University of \\ Oxford, Oxford OX3 7DQ, UK; folkeslk@gmail.com (L.K.F.); peterwardman@btinternet.com (P.W.) \\ 2 Departamento de Bioquímica, Facultad de Medicina, Universidad de la República, \\ Montevideo 11800, Uruguay; sbartesa@fmed.edu.uy (S.B.); madiat@fmed.edu.uy (M.T.) \\ 3 Centro de Investigaciones Biomédicas (CEINBIO), Universidad de la República, Montevideo 11800, Uruguay \\ * Correspondence: rradi@fmed.edu.uy
}

Citation: Folkes, L.K.; Bartesaghi, S.; Trujillo, M.; Wardman, P.; Radi, R. Radiolysis Studies of Oxidation and Nitration of Tyrosine and Some Other Biological Targets by Peroxynitrite-Derived Radicals. Int. J. Mol. Sci. 2022, 23, 1797. https:// doi.org/10.3390/ijms23031797

Academic Editor: Edward E. Schmidt

Received: 3 January 2022

Accepted: 2 February 2022

Published: 4 February 2022

Publisher's Note: MDPI stays neutral with regard to jurisdictional claims in published maps and institutional affiliations.

Copyright: (C) 2022 by the authors. Licensee MDPI, Basel, Switzerland. This article is an open access article distributed under the terms and conditions of the Creative Commons Attribution (CC BY) license (https:// creativecommons.org/licenses/by/ $4.0 /)$.

\begin{abstract}
The widespread interest in free radicals in biology extends far beyond the effects of ionizing radiation, with recent attention largely focusing on reactions of free radicals derived from peroxynitrite (i.e., hydroxyl, nitrogen dioxide, and carbonate radicals). These radicals can easily be generated individually by reactions of radiolytically-produced radicals in aqueous solutions and their reactions can be monitored either in real time or by analysis of products. This review first describes the general principles of selective radical generation by radiolysis, the yields of individual species, the advantages and limitations of either pulsed or continuous radiolysis, and the quantitation of oxidizing power of radicals by electrode potentials. Some key reactions of peroxynitrite-derived radicals with potential biological targets are then discussed, including the characterization of reactions of tyrosine with a model alkoxyl radical, reactions of tyrosyl radicals with nitric oxide, and routes to nitrotyrosine formation. This is followed by a brief outline of studies involving the reactions of peroxynitrite-derived radicals with lipoic acid/dihydrolipoic acid, hydrogen sulphide, and the metal chelator desferrioxamine. For biological diagnostic probes such as 'spin traps' to be used with confidence, their reactivities with radical species have to be characterized, and the application of radiolysis methods in this context is also illustrated.
\end{abstract}

Keywords: radiolysis; hydroxyl radicals; carbonate radicals; nitrogen dioxide radicals; tyrosine; dityrosine; nitric oxide; nitrotyrosine; lipoic acid; hydrogen sulfide; DMPO; desferrioxiamine

\section{Introduction}

Ionizing radiation produces free radicals, but damage to proteins by radicals is of much wider interest than the effects of radiation on cells and tissue. Appreciation of the involvement of free radicals in biology not arising from radiation grew dramatically following the identification of superoxide dismutase [1], a protein that catalysed disproportionation of superoxide radicals $\left(\mathrm{O}_{2}{ }^{\bullet-}\right)$ to form hydrogen peroxide $\left(\mathrm{H}_{2} \mathrm{O}_{2}\right)$. One area of early interest in free-radical biology $[2,3]$ was the possible generation of hydroxyl radicals $(\bullet \mathrm{OH})$ by Fenton chemistry $\left(\mathrm{Fe}^{(\mathrm{II})} / \mathrm{H}_{2} \mathrm{O}_{2}\right)$ [4,5]. A dramatic expansion of the scope of free radicals in biology followed the discovery of a role in biology for peroxynitrite (peroxynitrite refers to the sum of peroxynitrite anion $\left(\mathrm{ONOO}^{-}\right)$and its conjugated acid, peroxynitrous acid $(\mathrm{ONOOH}$, $\mathrm{pKa}=6.8)$ ) [6-10] formed by the reaction of $\mathrm{O}_{2}{ }^{\bullet-}$ with nitric oxide $\left({ }^{\bullet} \mathrm{NO}\right.$, nitrogen monoxide) (Figure 1), the latter initially identified to be biologically important as 'endothelium-derived relaxing factor' [11]. In the absence of targets, peroxynitrite rapidly decomposes to form $\bullet \mathrm{OH}$ and nitrogen dioxide $\left({ }^{\bullet} \mathrm{NO}_{2}\right)$ radicals (reviewed in [7]). This discovery was soon followed by the realization that in the presence of bicarbonate $/ \mathrm{CO}_{2}$, peroxynitrite could yield carbonate radicals $\left(\mathrm{CO}_{3}{ }^{--}\right)$[12] and rather powerful oxidants, further extending the range of biological free-radical oxidants [12-15]. Intriguingly, $\mathrm{CO}_{3}{ }^{\bullet-}$ has recently been implicated in Fenton-type chemistry [16,17]. 


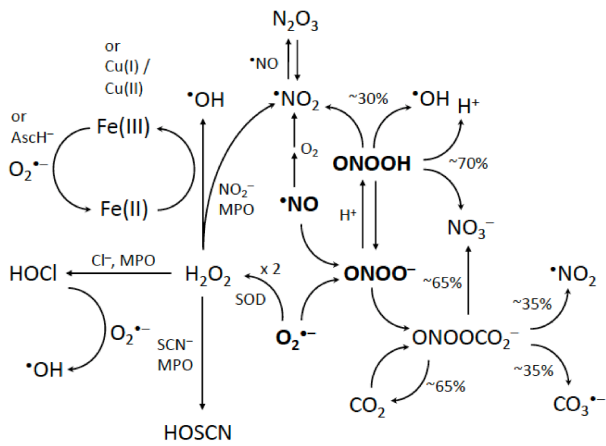

Figure 1. Pathways by which superoxide and nitric oxide can be converted to other oxidants in biology. The formation of peroxynitrite is emphasized. MPO, myeloperoxidase; $\mathrm{AscH}^{-}$, ascorbate.

The radiolysis of water generates three main free-radical species, as well as $\mathrm{H}_{2} \mathrm{O}_{2}$ and $\mathrm{H}_{2}$ : the hydrated electron $\left(e_{\mathrm{aq}}{ }^{-}\right)$, hydrogen atoms $\left(\mathrm{H}^{\bullet}\right)$ and ${ }^{\bullet} \mathrm{OH}\left(\mathrm{H}_{2} \mathrm{O}^{\bullet+}\right.$ is a very short-lived precursor). All are highly reactive towards proteins. However, in this article, reflecting the wider interests noted above, we focus on outlining and illustrating the use of radiolysis methods to generate specific, individual free radicals of interest in the context of peroxynitrite biochemistry and follow their reactions with amino acids, proteins, and other biologically relevant targets. The application and versatility of pulse radiolysis to studying biochemical redox processes has been reviewed by several authors [18-21]. Herein, we aim to provide both some background discussion and specific illustrations, seeking to complement these other reviews with a focus on how radiolysis studies were adapted and utilized for the biochemical characterization of peroxynitrite-derived radicals.

\section{Using Radiolysis to Probe Nitro-Oxidative Modifications to Amino Acids and Proteins}

\section{1. 'Converting' $e_{a q}{ }^{-}$and $\bullet \mathrm{OH}$ to Specific Oxidants}

We focus here on oxidative damage to proteins by free radicals. While oxidation formally corresponds to electron loss, ${ }^{\bullet} \mathrm{OH}$ are not known to oxidize aromatic systems by direct electron transfer. Thus, oxidation of phenolic compounds by ${ }^{\bullet} \mathrm{OH}$ involves a two-step process: addition to the ring and then elimination of water, a reaction catalysed by acid/base and phosphate [22,23]. However, there are many other potential sites of attack of $\bullet \mathrm{OH}$ on proteins where hydrogen abstraction can occur. Oxidation by other biologically-important radicals, (e.g., $\mathrm{CO}_{3}{ }^{\bullet-}$ and ${ }^{\bullet} \mathrm{NO}_{2}$ ), is more likely to involve direct electron transfer and the reactions of these oxidants or other free radicals which oxidize selectively by electron transfer have been of special interest. Saturation of aqueous solutions with nitrous oxide $(\sim 25 \mathrm{mM})$ removes $e_{\mathrm{aq}}{ }^{-}$and generates ${ }^{\bullet} \mathrm{OH}$ radicals in $<20 \mathrm{~ns}$ :

$$
e_{\mathrm{aq}}{ }^{-}+\mathrm{N}_{2} \mathrm{O}\left(+\mathrm{H}^{+}\right) \rightarrow \mathrm{N}_{2}+{ }^{\bullet} \mathrm{OH}
$$

Early studies on oxidation of tryptophan ( $\mathrm{TrpH})$ and tyrosine (TyrOH), either free or in peptides, exploited the selectivity of secondary inorganic oxidants $\left((\mathrm{SCN})_{2}{ }^{\bullet-}, \mathrm{Br}_{2}{ }^{\bullet-}, \mathrm{N}_{3}{ }^{\bullet}\right.$, $\mathrm{CO}_{3}{ }^{-}{ }^{-}, \mathrm{SeO}_{3}{ }^{\bullet-}$ and ${ }^{\bullet} \mathrm{NO}_{2}$ ) to oxidize these amino acids without secondary reactions such as $\mathrm{H}$-abstraction from side-chains [24-26]. These selective oxidants are easily generated by reaction of ${ }^{\bullet} \mathrm{OH}$ with the appropriate ion (e.g., $\mathrm{N}_{3}{ }^{-}$(Equation (2)), $\mathrm{NO}_{2}{ }^{-}$(Equation (3)), $\mathrm{CO}_{3}{ }^{2-}$ (Equation (4)) or $\mathrm{HCO}_{3}{ }^{-}$(Equation (5))),

$$
\begin{gathered}
\bullet \mathrm{OH}+\mathrm{N}_{3}{ }^{-}\left(+\mathrm{H}^{+}\right) \rightarrow \mathrm{H}_{2} \mathrm{O}+\mathrm{N}_{3} \cdot \\
\bullet \mathrm{OH}+\mathrm{NO}_{2}{ }^{-}\left(+\mathrm{H}^{+}\right) \rightarrow \mathrm{H}_{2} \mathrm{O}+\mathrm{NO}_{2} \\
\bullet \mathrm{OH}+\mathrm{CO}_{3}{ }^{2-}\left(+\mathrm{H}^{+}\right) \rightarrow \mathrm{H}_{2} \mathrm{O}+\mathrm{CO}_{3}{ }^{\bullet-} \\
\bullet \mathrm{OH}+\mathrm{HCO}_{3}{ }^{-} \rightarrow \mathrm{H}_{2} \mathrm{O}+\mathrm{CO}_{3}{ }^{\bullet-}
\end{gathered}
$$


By using a 100-fold excess concentration ratio of $\mathrm{N}_{3}{ }^{-}$to amino acid, the reaction of - $\mathrm{OH}$ with TrpH or TyrOH is easily avoided. A notable discovery using this approach was electron transfer between these two targets in proteins [27], which has been the subject of a number of investigations (e.g., [28]).

In many cases, oxidation may be accompanied by deprotonation. Thus, the radicalcations of phenols have $\mathrm{p} K_{\mathrm{a}}<0$ [29] and immediately deprotonate under physiological conditions, as does the bicarbonate radical [30]. Tryptophan radical-cations deprotonate with $\mathrm{p} K_{\mathrm{a}}=4.3$ [31]. Deprotonation, either of radicals or ground state, can have important consequences on both in the $\mathrm{pH}$-dependence of reduction potentials and the kinetics of electron-transfer reactions.

While, in principle, the design of such radiolysis experiments appears straightforward, there are limitations which are seldom discussed which do constrain the 'window' of kinetic information that can be obtained, and these are outlined below. The outstanding advantage of radiolysis as a technique to study radical reactions is that the concentrations of radicals are well-defined, and controllable, but even the radical yields need careful attention in deriving quantitative information such as extinction coefficients of species and the rate constants for radical-radical reactions.

\subsection{Yields of Radicals Produced by the Radiolysis of Water}

Confusingly, radiation chemists express yields (the amount or concentration of species produced per unit radiation dose) in different ways. The SI unit of absorbed dose is the gray $(1 \mathrm{~Gy}=1 \mathrm{~J} / \mathrm{kg})$ and yields in mol J ${ }^{-1}$ equate to concentrations of $\mathrm{M} \mathrm{Gy}^{-1}\left(\mathrm{~mol} \mathrm{~L}^{-1} \mathrm{~Gy}^{-1}\right)$ for solutions of unit density. However, before the adoption of the gray in 1975, doses were expressed either in rads $\left(1 \mathrm{rad}=100 \mathrm{erg} \mathrm{g}^{-1}=0.01 \mathrm{~Gy}\right)$ or $\mathrm{eV} \mathrm{g}^{-1}\left(1 \mathrm{eV} \sim 1.602 \times 10^{-19} \mathrm{~J} ; 1 \mathrm{~Gy}\right.$ $\left.\sim 6.242 \times 10^{15} \mathrm{eV} \mathrm{g}^{-1}\right)$. Due to the cumbersome numbers, radiation chemists defined yields in terms of a $G$ value, in units of molecules $(100 \mathrm{eV})^{-1}$. This use is still quite common, but to add to confusion, the symbol $G$ is often used for yields expressed in either way: 1 molec $(100 \mathrm{eV})^{-1}$ $\sim 0.1036 \mu \mathrm{M} \mathrm{Gy}^{-1}$ for water. We use the SI formalism here.

Radiolysis of liquid water at ambient temperatures results in $\sim 0.5 \mu \mathrm{M}$ ionizations per gray absorbed dose: picoseconds after the ionization event, the yield of ejected, hydrated electrons $\left(e_{\mathrm{aq}}{ }^{-}\right)$is $\sim 0.48 \mu \mathrm{M} \mathrm{Gy}^{-1}$ [32]. However, the ionization events occur in tracks or clusters, and some species close together recombine. By the time diffusion has resulted in a homogeneous distribution of species $(\sim 0.1-0.2 \mu \mathrm{s})$, the yield of $e_{\mathrm{aq}}{ }^{-}$is almost halved. It is common to summarize the species produced from water radiolysis by equations of the form:

$$
\mathrm{H}_{2} \mathrm{O} \rightarrow e_{\mathrm{aq}}{ }^{-}(0.27)+{ }^{\bullet} \mathrm{OH}(0.28)+\mathrm{H}^{\bullet}(0.06)+\mathrm{H}_{2} \mathrm{O}_{2}(0.070)+\mathrm{HO}_{2}^{\bullet}(0.0008)
$$

where the yields in parentheses here are in $\mu \mathrm{M} \mathrm{Gy}^{-1}$; the values in molec $(100 \mathrm{eV})^{-1}$ are close to $10 \times$ higher [33]. The numbers vary with different types of radiation: those above refer to irradiation of water by gamma rays or megavoltage electrons. It is important to note that the yields in Equation (6) refer only to very dilute solutions. Adding reactive chemicals or 'scavengers' increases the amount of water radicals scavenged since the track recombination events are intercepted. With the high concentration of scavenger in the case of $\mathrm{N}_{2} \mathrm{O}$-saturated water, the yield of $e_{\mathrm{aq}}{ }^{-}$'converted' to ${ }^{\bullet} \mathrm{OH}$ by Equation (1) is $\sim 0.33 \mu \mathrm{M} \mathrm{Gy}^{-1}$ rather than the value of $\sim 0.27 \mu \mathrm{M} \mathrm{Gy}^{-1}$ shown in Equation (6). Further, as noted above, another common practice is again to 'convert' $\bullet \mathrm{OH}$ radicals to specific oxidizing radicals of interest, by adding high concentration of appropriate scavengers (Equations (2)-(5)), and the combination of high concentrations of scavengers of both $e_{\mathrm{aq}}{ }^{-}\left(\mathrm{N}_{2} \mathrm{O}\right)$ and ${ }^{\bullet} \mathrm{OH}$ results in yields of secondary oxidants (e.g., by Equation (2)) which can be as high as $\sim 0.7 \mu \mathrm{M} \mathrm{Gy}^{-1}$, rather than the value of $\sim 0.55 \mu \mathrm{M} \mathrm{Gy}^{-1}$, the sum of the yields of $e_{\mathrm{aq}}{ }^{-}$and ${ }^{\bullet} \mathrm{OH}$ in Equation (6). There is a useful, semi-empirical equation to predict the yields in such circumstances for different 
- $\mathrm{OH}$ scavengers in $\mathrm{N}_{2} \mathrm{O}$-saturated water containing an ${ }^{\bullet} \mathrm{OH}$ scavenger $\mathrm{S}$, the 'WarmanAsmus-Schuler Equation' [33]:

$$
\left[{ }^{\bullet} \mathrm{OH}\right] \text { scavenged } / \mu \mathrm{M} \mathrm{Gy}^{-1} \sim 0.54+0.32\left(k[\mathrm{~S}] / \lambda^{\frac{1}{2}} /\left(1+(k[\mathrm{~S}] / \lambda)^{\frac{1}{2}}\right)\right.
$$

where $k$ is the rate constant for reaction of ${ }^{\bullet} \mathrm{OH}$ with $\mathrm{S}$ and $\lambda=4.7 \times 10^{8} \mathrm{~s}^{-1}$. Using Equation (7), if $k[\mathrm{~S}]=5 \times 10^{8} \mathrm{~s}^{-1}$, then the yield of ${ }^{\bullet} \mathrm{OH}$ scavenged is $\sim 0.70 \mu \mathrm{M} \mathrm{Gy}^{-1}$.

Thus, the yields of free radicals produced by irradiation of different aqueous solutions are known, reliably, to within a few percent. This is a major asset in applying radiation chemistry to study free radicals. Not only are the concentrations of radicals known, but the radicals can be produced either at a known, constant rate which can be varied by orders of magnitude simply by varying the radiation intensity, or a known concentration of radicals can be produced in a solution 'instantaneously' (for our purposes) using sub-microsecond pulses of radiation.

\subsection{Measuring Rate Constants Using Radiation-Chemical Generation of Radicals: Some Limitations}

Observing reactions in real time following pulse radiolysis seems at first sight to be a major advantage over inferences from final product analysis, but the method does have its limitations. Typically, doses of up to a few grays are delivered in a fraction of a microsecond. Noting the yields in Equation (6), this corresponds to producing radical concentrations in the micromolar range. Most studies use spectrophotometric detection with (typically) a time window for real-time observation of radicals of sub-microseconds to seconds. While for some specific purposes, e.g., studying spontaneous disproportionation of $\mathrm{HO}_{2}{ }^{\bullet} / \mathrm{O}_{2}{ }^{\bullet-}$ radicals, considerably higher doses/radical concentrations are used, it is generally advantageous to use the lowest dose possible. This is due to the fact that in the majority of experiments it is desired to study a reaction of a radical $\mathrm{R}^{\bullet}$ with a specific solute $S$ (Equation (8)), while minimizing unwanted contributions of radical/radical reactions (Equation (9)):

$$
\mathrm{R}^{\bullet}+\mathrm{S} \rightarrow \text { product(s) }
$$

$$
\mathrm{R}^{\bullet}+\mathrm{R}^{\bullet} \rightarrow \text { combination or disproportionation products. }
$$

Since many radical/radical reactions have rate constants approaching the diffusioncontrolled limit $\left(>10^{9} \mathrm{M}^{-1} \mathrm{~s}^{-1}\right)$ the first half-life of reaction (9) might well be $<500 \mu \mathrm{s}$ even if the initial radical concentration is only (say) $1 \mu \mathrm{M}$. A common scenario is to use the primary water radicals $\left(e_{\mathrm{aq}}{ }^{-} /{ }^{\bullet} \mathrm{OH} / \mathrm{H}^{\bullet}\right)$ to generate a secondary radical (e.g., ${ }^{\bullet} \mathrm{NO}_{2}, \mathrm{CO}_{3}{ }^{\bullet-}$ or GS $\left.{ }^{\bullet}\right)$ and monitor the reactions of the latter with the target $\mathrm{S}$, reaction (8). This places limits on the concentrations of solute $\mathrm{S}$, since it must be much lower than the concentration of the main radical scavenger (e.g., $\mathrm{Br}^{-}, \mathrm{N}_{3}{ }^{-}, \mathrm{NO}_{2}{ }^{-}, \mathrm{HCO}_{3}{ }^{-} / \mathrm{CO}_{3}{ }^{2-}, \mathrm{GSH}$ ), to avoid direct reactions of the water radicals with $\mathrm{S}$. In turn, limiting the concentration of $S$ to (say) $0.5 \mathrm{mM}$ to achieve this aim might mean the half-life of reaction (8) might be $>140 \mu$ s (i.e., quite possibly within the same time range as reaction (9), if the rate constant $k_{5}$ was as low as $10^{7} \mathrm{M}^{-1} \mathrm{~s}^{-1}$; there are many reactions of interest with much lower rate constants). Thus, the design of many experiments involves careful consideration of competing reactions if reaction (8) is to dominate over reaction (9), and there are many reactions of interest which are simply too slow to be accessible due to the constraints outlined above. For the peroxynitrite-derived oxidant $\mathrm{CO}_{3}{ }^{\bullet-}$ (Equations (4) and (5)) which is observed by kinetic spectrophotometry at $605 \mathrm{~nm}$ (Figure 2), the rate of loss of absorbance with increasing concentrations of $S$ is used to estimate rate constants for reactions with a target $\mathrm{S}$. Studying reactions of $\mathrm{CO}_{3}{ }^{-}$at physiological $\mathrm{pH}$ is complicated with the potential requirement of $\mathrm{CO}_{2}$. 

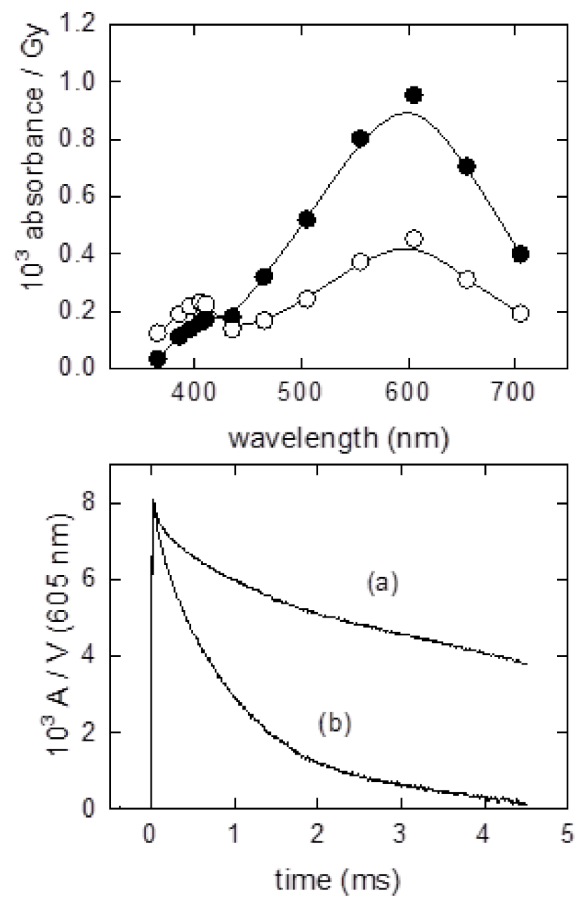

Figure 2. Upper: examples of transient absorption spectra of $\mathrm{CO}_{3}{ }^{\bullet-}$ generated following pulse radiolysis of a solution of $40 \mu \mathrm{M} \mathrm{N}$-t-BOC-L-tyrosine tert-butyl ester (BTBE) incorporated with liposomes prepared with egg yolk phosphatidyl choline at $\mathrm{pH} 8,100 \mu \mathrm{s}$ (filled circles) and $500 \mu \mathrm{s}$ (empty circles) after a $15 \mathrm{~Gy}, 500 \mathrm{~ns}$ pulse (note the formation of absorption at $405 \mathrm{~nm}$ indicative of the formation of $\mathrm{TyrO}^{\bullet}$ ). Lower: example transients showing decay of the absorption (A) of $\mathrm{CO}_{3}{ }^{\bullet-}$; (a) with no BTBE and (b) with $40 \mu \mathrm{M}$ BTBE present.

Steady-state (continuous) radiolysis to generate radicals is useful in many instances. This is because at low dose rates (of the order of perhaps $1 \mathrm{~Gy} \mathrm{~s}^{-1}$ or lower), the steady-state concentrations of radicals $\mathrm{R}^{\bullet}$ are so low that reactions of the type of (9) then contribute negligibly, and so even slow reactions (8) of specific radicals with targets can proceed with high specificity. In addition, the ability to generate radicals with a widely-varying, more biomimetic range of production rates is often of value. Even if low dose rate radiolysis can overcome problems such as reaction (9) no longer competing with (8), there may still be constraints: for example, using gamma radiolysis to oxidize $\mathrm{TyrOH}$ using $\mathrm{Br}_{2}{ }^{\bullet-}$, while radical/radical self-reaction of the oxidant could be neglected, even $1.8 \mu \mathrm{M}$ nitric oxide was sufficient to intercept a significant fraction of $\mathrm{Br}_{2}{ }^{\bullet-}$ in competition with $500 \mu \mathrm{M} \mathrm{TyrOH}$. This is so because the reactivity of $\mathrm{NO}^{\bullet}$ towards $\mathrm{Br}_{2}{ }^{\bullet-}$ is very much higher than reaction of the latter radical with TyrOH (see Section 4). Solubilising agents such as DMSO can cause unexpected problems. DMSO is an efficient scavenger of ${ }^{\bullet} \mathrm{OH}$ and can reduce the radical yield of $\bullet \mathrm{OH}$ as well as produce $\mathrm{CH}_{3} \bullet$ radicals.

Fortunately, several thousand rate constants are readily accessible in the literature to assist with experimental design. Thus carefully-evaluated recommendations for rate constants for reactions of $e_{\mathrm{aq}}{ }^{-} /{ }^{\bullet} \mathrm{OH} / \mathrm{H}^{\bullet}$ have been assembled [34,35]. Other compilations include reactions of $\mathrm{HO}_{2}{ }^{\bullet} / \mathrm{O}_{2}{ }^{\bullet-}$ [36]; peroxyl radicals [37]; phenoxyl radicals [38]; inorganic radicals [39]; aliphatic carbon-centered radicals [40]; and metal ions and metal complexes [41], all in aqueous solutions.

\subsection{It Is Important Not to Overlook Minor Reactions}

Hydrogen atoms comprise only around 10\% of the water radicals in Equation (6) and their production is therefore often neglected. However, only in studying superoxide radical reactivity with oxygenated solutions containing formate to scavenge ${ }^{\bullet} \mathrm{OH}$ and generate the reductant $\mathrm{CO}_{2}{ }^{\bullet-}$, where $\mathrm{HO}_{2}{ }^{\bullet} / \mathrm{O}_{2}{ }^{\bullet-}$ are the only radicals present within $1-2 \mu$ s after 
the end of a radiation pulse, do we encounter really 'clean' radical production. The 'minor' product $\mathrm{H}^{\bullet}$ could be a significant interference, especially in oxygenated solutions due to the diffusion-controlled reaction of $\mathrm{H}^{\bullet}$ with $\mathrm{O}_{2}$ to form superoxide.

\subsection{Reduction (Electrode) Potentials of Radicals as a Guide to Reactivity}

The rate constants of many redox reactions reflect the 'energy gap' quantified by the reduction potentials of the couples involved [42]. Thus, the rates of oxidation of phenols catalyzed by peroxidase enzymes have been interpreted in terms of the Marcus relationship for electron-transfer reactions [43], but there are numerous other examples where the 'energy gap' is reflected in the reaction kinetics [44]. Reduction potentials characterize the reaction:

$$
\text { oxidant }+e^{-} \rightleftharpoons \text { reductant }
$$

and is represented by $E$ (oxidant/reductant), where variants such as $E^{\circ}$ may define a standard potential (reactants/products with unit activity), $E^{\circ \prime}$ to reflect quasi-standard conditions such as $\mathrm{pH} 7$ when protons are involved in the couple, or subscripted with $m$ and/or $i$ to indicate mid-point potentials at $\mathrm{pH}_{i}$ [45]. Radiation chemistry has contributed enormously to characterizing reduction potentials of couples involving radicals where either oxidant or reductant is short-lived in aqueous solution, by measuring the equilibrium constants of reversible equilibria involving the radicals and redox indicators of known electrode potential [46]. Table 1 lists some reduction potentials of couples of relevance to radiationchemical studies of free-radical oxidative damage to amino acids at $\mathrm{pH} 7$ [45]. The higher the value, the more powerful the oxidant. The bromide, azide, and thiocyanate couples are included as they have been used extensively as one-electron oxidants in model studies.

Table 1. Reduction (electrode) potentials of biologically relevant redox pairs at $\mathrm{pH} 7^{a}$.

\begin{tabular}{|c|c|}
\hline Couple (Oxidant/Reductant) & $E^{\circ /} / \mathrm{V}$ \\
\hline - $\mathrm{OH}, \mathrm{H}^{+} / \mathrm{H}_{2} \mathrm{O}$ & 2.32 \\
\hline $\mathrm{Br}_{2}{ }^{\bullet-} / 2 \mathrm{Br}^{-}$ & 1.63 \\
\hline $\mathrm{CO}_{3}^{\bullet-} / \mathrm{CO}_{3}^{2-}$ & 1.57 \\
\hline $\mathrm{N}_{3} \bullet / \mathrm{N}_{3}^{-}$ & 1.33 \\
\hline$(\mathrm{SCN})_{2}^{\bullet-} / 2 \mathrm{SCN}^{-}$ & 1.30 \\
\hline$\cdot \mathrm{NO}_{2} / \mathrm{NO}_{2}^{-}$ & 1.04 \\
\hline $\operatorname{Trp}{ }^{\bullet}, \mathrm{H}^{+} / \operatorname{Trp} \mathrm{H}^{b}$ & 1.03 \\
\hline $\mathrm{GS}^{\bullet}, \mathrm{H}^{+} / \mathrm{GSH}^{c}$ & 0.94 \\
\hline $\operatorname{TyrO}^{\bullet}, \mathrm{H}^{+} / \mathrm{TyrOH}^{d}$ & 0.91 \\
\hline $\mathrm{LOO}^{\bullet}, \mathrm{H}^{+} / \mathrm{LOOH}$ & 1.01 \\
\hline $\mathrm{LO}^{\bullet}, \mathrm{H}^{+} / \mathrm{LOH}$ & 1.76 \\
\hline $\mathrm{HS}^{\bullet}, \mathrm{H}^{+} / \mathrm{H}_{2} \mathrm{~S}$ & 0.93 \\
\hline
\end{tabular}

${ }^{a}$ Ref. [45]; typical uncertainty $\pm 0.02 \mathrm{~V} .{ }^{b} \mathrm{TrpH}$, tryptophan; ${ }^{c} \mathrm{GSH}$, glutathione, ref. [47]; ${ }^{d} \mathrm{TyrOH}$, tyrosine.

It should be noted that the reduction potentials of the amino acids will vary when incorporated in a peptide or protein, not least due to the fact that the prototropic properties may be changed from those in free solution, as well as the degree of hydration. Further, while nominally ${ }^{\bullet} \mathrm{OH}$ is the most powerful oxidant, it may react by addition/elimination reactions as noted above, or hydrogen abstraction rather than electron transfer. Of the biological peroxynitrite-derived oxidants, $\mathrm{CO}_{3}^{\bullet-}$ is significantly more powerful than ${ }^{\bullet} \mathrm{NO}_{2}$, and only participates in hydrogen abstraction reactions [48].

\section{Oxidation of Tyrosine and the 'Repair' of the Tyrosyl Radical}

TyrOH is a critical component of many proteins and is also an essential precursor to the formation of catecholamines, melanin and thyroxine, and levels of $\mathrm{TyrOH}$ in the body are closely regulated. It is one of the most easily oxidizable amino acids by nonenzymatic reactions. The oxidation of tyrosine residues to phenoxyl radicals (TyrO`), sometimes predominating as a stable amino acid radical, is essential for some enzymatic functions [49,50]. 3,3'-Dityrosine (diTyr) is also an enzymatically-controlled cross-link of 
TyrOH maintaining functionality of some proteins [51]. The ability of biological oxidants to generate $\mathrm{TyrO}^{\bullet}$ is of much interest [14]. Importantly, TyrOH does not react directly with peroxynitrite at appreciable rates [52], but rather with peroxynitrite-derived radicals that promote its one-electron oxidation to $\mathrm{TyrO}^{\bullet}$ and its subsequent evolution to 3-nitrotyrosine, diTyr and 3-hydroxytyrosine [7]. Earlier work involved studies of oxidation of TyrOH by $\bullet \mathrm{OH}$ and secondary oxidants such as $\mathrm{N}_{3} \bullet$ (e.g., $[27,28]$ ). The stable products following one-electron oxidation of TyrOH depend upon the availability of antioxidants [53,54]; in physiological conditions reactions of $\mathrm{TyrO}^{\bullet}$ with ascorbate (Equation (11)) can be favored over those with glutathione (GSH) (Equation (12)) [55].

$$
\begin{gathered}
\mathrm{TyrO}^{\bullet}+\mathrm{AscH}^{-} \rightarrow \mathrm{TyrOH}+\mathrm{AscH}^{\bullet} \\
\mathrm{TyrO}^{\bullet}+\mathrm{GSH}
\end{gathered}
$$

\subsection{Kinetics of Reduction of Tyrosine Phenoxyl Radicals By Glutathione}

Thiols can compete with targets such as TyrOH for reaction with oxidants, but they can also 'repair' oxidative damage to proteins. The lifetime and fate of TyrO' in biological systems is largely driven by the availability and proximity of oxidants and reductants. We investigated the reaction between $\mathrm{TyrO}^{\bullet}$ radicals and GSH [53]. The formation of diTyr, from the combination of two TyrO ${ }^{\bullet}$ (Equation (13)) can reflect oxidative damage; diTyr is fluorescent and thus easy to measure. Other secondary oxidation products, involving tyrosyl radicals, include isodityrosine, and the tyrosine trimers such as trityrosine and pulcherosine [56,57] (Figure 3).

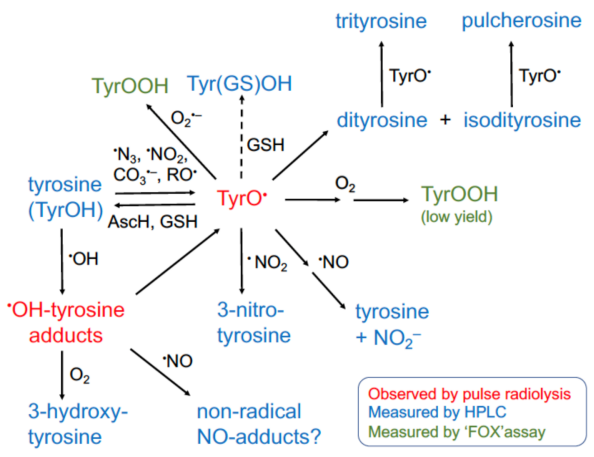

Figure 3. Pathways of free-radical reactions with tyrosine which can be monitored by pulse radiolysis or HPLC (with absorbance, fluorescence and mass spectrometric detection) following steady-state radiolysis. Chemical structures of products showed in the figure can be found in the following references [7,56-61]. A putative structure of a tyrosine-glutathione adducts formed from the reaction of the $\mathrm{TyrO}^{\bullet}-\mathrm{GS}^{\bullet}$ radical intermediates (dashed arrow) has been inferred from [53].

$3,3^{\prime}$-Dityrosine being a product of radical dimerization, reductive processes which 'repair' tyrosyl radicals can compete to decrease or eliminate the yields of diTyr. GSH reacts with $\mathrm{TyrO}^{\bullet}$ with an estimated rate constant of $2 \times 10^{6} \mathrm{M}^{-1} \mathrm{~s}^{-1} \mathrm{pH} 7.15$ [53]. Figure 3 illustrates which radiolysis methods can be used to study these reactions. To determine the rate constant, $\mathrm{TyrO}^{\bullet}$ were generated by pulse radiolysis and monitored by kinetic spectrophotometry at $405 \mathrm{~nm}$. Proposals of a possible equilibrium existing in the 'repair' reaction were also investigated. By observing the fast redox equilibrium with the indicator 2,2'-azinobis(3-ethylbenzothiazoline-6-sulphonate), the reduction (electrode) potential of the $\left(\mathrm{TyrO}^{\bullet}, \mathrm{H}^{+} / \mathrm{TyrOH}\right)$ couple was estimated. The mid-point reduction potential of $\mathrm{TyrO}^{\bullet}$ at $\mathrm{pH} 7, E_{\mathrm{m} 7}\left(\mathrm{TyrO}^{\bullet}, \mathrm{H}^{+} / \mathrm{TyrOH}\right)=0.93 \pm 0.02 \mathrm{~V}$ was found to be close to that of the glutathione thiyl radical $\left(\mathrm{GS}^{\bullet}\right), E_{\mathrm{m} 7}=0.94 \pm 0.03 \mathrm{~V}$ [47]. The 'repair' equilibrium for the reaction of $\mathrm{TyrO}^{\bullet}$ with GSH (Equation (12)) suggested that the reaction might require removal of $\mathrm{GS}^{\bullet}$ (expected to be the preliminary radical product of GSH). This could occur 
via dimerization (Equation (14)), conjugation with thiol/thiolate (Equation (15)) or $\mathrm{O}_{2}$ (Equation (16)), to move the equilibrium in the direction of repair.

$$
\begin{gathered}
2 \mathrm{TyrO}^{\bullet} \rightarrow 3,3^{\prime} \text {-dityrosine } \\
\mathrm{GS}^{\bullet}+\mathrm{GS}^{\bullet} \rightarrow \mathrm{GSSG}^{-} \\
\mathrm{GS}^{\bullet}+\mathrm{GS}^{-} \rightleftharpoons(\mathrm{GSSG})^{\bullet-} \\
\mathrm{GS}^{\bullet}+\mathrm{O}_{2} \rightleftharpoons(\mathrm{GSOO})^{\bullet}
\end{gathered}
$$

Products from the reaction of $\mathrm{TyrO}{ }^{\bullet}$ with GSH were monitored using HPLC with absorbance, fluorescence and mass spectrometry used for detection. Oxidised GSH (GSSG) was detected following steady-state radiolysis, with the concomitant loss in the formation of diTyr with an increase in remaining GSH concentration.

However, yields of GSSG were not equal to $2 \times$ the loss of GSH, suggesting that parallel reactions may be occurring. Indeed, evidence was seen for the formation of a conjugate of TyrOH with GSH (potentially a tyrosine thioether with GSH substituted at the $3^{\prime}$ position). Whether this product would be observed or be formed in a cellular system is unknown. The reaction of tyrosyl radical and superoxide radical has been reported [62] and it mainly yields tyrosyl hydroperoxide. This oxidized tyrosine derivative can be formed and be reactive in peptides and proteins in vitro [63-65], and possibly at sites of inflammation in vivo.

\subsection{Kinetics of Oxidation of Tyrosine by a Model Alkoxyl Radical and Free-Radical Reactions in Hydrophobic Membranes}

The formation and fate of the radical intermediates in different environments and proteins is not fully understood. The microenvironment may have a large effect on the reactivity of TyrOH and its radicals [66]. In membrane proteins, diffusion of oxidants into lipid bilayers may be hindered [67] and lateral movement of $\mathrm{TyrO}{ }^{\bullet}$ units within the membrane to allow dimerization or other conjugations to occur may be severely restricted. These physicochemical factors influencing tyrosine nitration in membranes may differ from those in aqueous solution and therefore, understanding the biochemical changes to $\mathrm{TyrOH}$ within a hydrophobic environment following oxidative and nitrosative stress is important [58]. Many determinants have to be taken into account, such as facilitated diffusion of ${ }^{\bullet} \mathrm{NO}_{2}$ towards membranes, exclusion of antioxidants normally present in aqueous phases such as ascorbate and GSH, solvent accessibility to tyrosine residues and presence of fatty acids which undergo lipid peroxidation reactions [68]. Tyrosine nitration and lipid peroxidation may be linked, since lipid radicals may oxidize $\mathrm{TyrOH}$, fueling nitration pathways in membranes $[69,70]$.

Incorporating TyrOH within hydrophobic compounds such as $\mathrm{N}$-t-BOC L-tyrosine tert-butyl ester (BTBE) offers the possibility of studying aqueous micellar suspensions, liposomes, and biomembranes [66,67,69-72]. Although this presents additional constraints from scattered light in pulse radiolysis studies, extraction of products from micellar suspensions following gamma-radiolysis permits chromatographic analysis. A rate constant for reaction of lipid peroxyl radicals with BTBE has been estimated as $4.8 \times 10^{3} \mathrm{M}^{-1} \mathrm{~s}^{-1}$ [70] Similar reactions with alkoxyl radicals (also intermediates in lipid peroxidation) were investigated using steady-state and pulse radiolysis [73].

The tert-butoxyl radical $\left(t-\mathrm{BuO}^{\bullet}\right)$ generated from radiolysis of aqueous solutions of tertbutyl hydroperoxide was used as a model alkoxyl radical of similar reactivity to those generated from lipid peroxides [73,74]. The reaction of $t-\mathrm{BuO}^{\bullet}$ with $\mathrm{TyrOH}$ was followed by steady-state radiolysis with competition kinetics, measuring acetone by LCMS, which is produced from the $\beta$-fragmentation of $t$ - $\mathrm{BuO} \bullet$ [73]. The concentration of $\mathrm{TyrOH}$ and $\mathrm{pH}$ of the solutions reduced the yield of acetone and the rate constant for the reaction between $t$ - $\mathrm{BuO}{ }^{\bullet}$ and $\mathrm{TyrOH}$ was estimated as $6 \times 10^{7} \mathrm{M} \mathrm{s}^{-1}$ at $\mathrm{pH} 10$. The reaction was also followed by pulse radiolysis by measuring the formation of TyrO ${ }^{\bullet}$ by kinetic spectrophotometry at $405 \mathrm{~nm}$. The initial yield of $\mathrm{TyrO}^{\bullet}$ as a function of $\mathrm{TyrOH}$ concentration allowed the rate constant for the reaction between 
$t$ - $\mathrm{BuO} \mathrm{O}^{\bullet}$ and $\mathrm{TyrOH}$ to be estimated as $7 \pm 3 \times 10^{7} \mathrm{M}^{-1} \mathrm{~s}^{-1}$ at $\mathrm{pH} 10$. As the reaction was not observable at $\mathrm{pH} 7$ it was concluded that $t$ - $\mathrm{BuO} \bullet$ preferentially oxidizes tyrosine phenolate rather than the phenol. The $\mathrm{p} K_{\mathrm{a}}$ of phenolic hydroxyl dissociation in $\mathrm{TyrOH}$ is $\sim 10.3$, which infers that at $\mathrm{pH} 7.4$ the rate constant is much lower, about $3 \times 10^{5} \mathrm{M}^{-1} \mathrm{~s}^{-1}$. This is still significantly higher than that estimated for similar reactions by lipid peroxyl radicals [70]. However, further work is required to fully understand how lipid radicals themselves may oxidize membrane proteins in cells. Polyunsaturated fatty acids in a membrane can undergo intramolecular cyclization to epoxy-allylic radicals upon oxidation, which can combine with $\mathrm{O}_{2}$ to create secondary peroxyl radicals [75]. It may be that reactions with alkoxyl radicals are restricted to $\mathrm{TyrOH}$ residues close to the lipid-water interface; protein-derived alkoxyl radicals may have different reactivity to lipid alkoxyl radicals.

The decomposition of peroxynitrite generates a mixture of radicals at neutral $\mathrm{pH}$ (Figure 1). Using steady state radiolysis, radiolysis intermediates and products of $\mathrm{TyrOH}$ within BTBE were found to be similar to those of free TyrOH in aqueous solution (L.K. Folkes, personal communication; see Figure 2, lower panel, as well) and to those observed following reaction with peroxynitrite. However, the efficiency of nitration of $\mathrm{TyrOH}$ by peroxynitrite was more effective in hydrophobic compared to in aqueous conditions [66]. The yields of products (especially dimerized BTBE) were dependent upon the saturation of the lipids used to prepare the micelles, with dimerization being higher where unsaturated fatty acids were incorporated. This enhanced dimerization could be related to changes in the fluidity of the membranes (as unsaturated fatty acids create more fluidity) or through secondary reactions with lipids or lipid radicals, including competition reactions of the initiating radicals themselves with lipids. Further reactions of BTBE are discussed in Section 5 .

\section{Involvement of Nitric Oxide and Oxygen in Reactions of Tyrosyl Radicals}

The Effects of Nitric Oxide or Oxygen on the Stable Products Formed from the Tyrosine Phenoxyl Radical and Tyrosine Hydroxyl Radical Adducts

Reactions of tyrosyl radicals with nitric oxide and oxygen are illustrated in Figure 3 and [76]. The variety of radicals from the decomposition of peroxynitrite (Figure 1) complicates the determination and identification of individual radical reactions. Pulse radiolysis allows the rates of reactions of $\mathrm{TyrOH}$ with peroxynitrite-derived radicals to be measured, and the lifetimes of radical intermediates to be compared in the absence and presence of other reactants (such as ${ }^{\bullet} \mathrm{NO}$ or $\mathrm{O}_{2}$ ). The controlled production of tyrosyl radicals with steady state radiolysis allows yields of subsequent products, including diTyr, 3-nitrotyrosine, and 3-hydroxytyrosine (L-dopa) to be measured for individual oxidizing radicals.

Reactions of TyrOH with ${ }^{\bullet} \mathrm{NO}_{2}$ and $\mathrm{CO}_{3}{ }^{-}$proceed through the intermediate formation of $\mathrm{TyrO} \boldsymbol{\bullet}^{\bullet}$ which react very slowly with $\mathrm{O}_{2}[54,76]$ and very rapidly with $\bullet \mathrm{NO}$ [77]. Hydroxyl radical reacts with $\mathrm{TyrOH}$ through addition/elimination reactions forming ${ }^{\bullet} \mathrm{OH}-$ adduct intermediates at the ortho or meta position [78,79]. In comparison to reactions with TyrO ${ }^{\bullet}, \mathrm{O}_{2}$ reacts rapidly with the $\mathrm{C}-3\left({ }^{\bullet} \mathrm{OH}\right)-\mathrm{TyrOH}$ adduct (ortho), forming L-dopa [80], whilst releasing superoxide. In the absence of, or with only low concentrations of $\mathrm{O}_{2}$, the ortho $\mathrm{C}-3\left({ }^{\bullet} \mathrm{OH}\right)-\mathrm{TyrOH}$ adduct can dehydrate forming $\mathrm{TyrO}^{\bullet}[79]$, the same radical produced by reaction of TyrOH with $\mathrm{NO}_{2}{ }^{\bullet}$ and $\mathrm{CO}_{3}{ }^{--}$, in a reaction which is acid/base catalysed (including by phosphate $\left(\mathrm{HPO}_{4}{ }^{2-}\right)[23,81]$. In comparison, the meta position $\mathrm{C}-4\left({ }^{\bullet} \mathrm{OH}\right)-\mathrm{TyrOH}$ adduct is thought to decay through second-order reactions and does not dehydrate to form $\mathrm{TyrO}^{\bullet}[79]$.

Using pulse and gamma radiolysis, it has been shown that ${ }^{\bullet} \mathrm{NO}_{2}$ reacts with $\mathrm{TyrOH}$ to form TyrO ${ }^{\bullet}$ [26], and 3-nitrotyrosine (unique to radical reactions with ${ }^{\bullet} \mathrm{NO}_{2}$ ) through secondary radical-radical reactions with ${ }^{\bullet} \mathrm{NO}_{2}$. In the presence of hundreds of micromolar of $\mathrm{O}_{2}$, a small decrease in the formation of these products is observed, with some evidence of low yields of hydroperoxide being formed, but no 3-hydroxytyrosine has been identified [76]. In contrast, in the presence of micromolar concentrations of ${ }^{\bullet} \mathrm{NO}$, the loss of $\mathrm{TyrOH}$ is very low. Evidence exists for the probable formation of an unstable intermediate regenerating TyrOH and forming nitrite. It is important to point out that the reaction of 
tyrosyl radical with oxygen is rather slow, in contrast to what is observed with other amino acid derived radicals $[76,82]$.

Hydroxyl radicals react with TyrOH through intermediate adducts, forming diTyr. In the presence of micromolar concentrations of $\mathrm{O}_{2}$ the yields of diTyr are reduced and 3-hydroxytyrosine is formed. In contrast, in the presence of micromolar concentrations of - $\mathrm{NO}$ the loss of TyrOH is similar to that in the absence of $\bullet \mathrm{NO}$ but the yields of diTyr are extremely low [83]. There are probably intermediate non-radical ${ }^{\bullet} \mathrm{NO}$-adducts with the - $\mathrm{OH}$-adducts of TyrOH. These radical-radical reactions could 'fix' the damage to TyrOH from reaction with ${ }^{\bullet} \mathrm{OH}$ but in doing so could alter metabolic functions of proteins or yields of metabolic compounds by altering TyrOH. Changes in the levels from expected basal concentrations of stable products resulting from $\mathrm{TyrO}^{\bullet}$ can be indicative of oxidative and/or nitrative stress.

Whilst reactions of TyrOH with peroxynitrite-derived radicals can be followed by chromatography techniques, diTyr can be derived from multiple peroxynitrite-derived free-radicals and therefore may not reflect the source of the initial oxidizing radical. Also, secondary reactions producing products such as 3-nitrotyrosine are likely to be different in yield from a 'bolus' addition of peroxynitrite compared to ionizing radiation, especially in a heterogeneous medium. Utilizing multiple techniques can improve mechanistic understanding.

\section{Reactions of Other Biological Targets Towards Peroxynitrite-Derived Radicals}

\subsection{Carbonate and Nitrogen Dioxide Radicals Readily React with Lipoic and Dihydrolipoic Acid}

Lipoic acid (LA) and its reduced form dihydrolipoic acid (DHLA) play a major role in cellular metabolism and have redox functions [84]. Peroxynitrite reacts with LA and DHLA with second-order rate constants of 1400 and $500 \mathrm{M}^{-1} \mathrm{~s}^{-1}$, respectively [85], too low for these compounds to protect against peroxynitrite-mediated damage in vivo. In contrast, peroxynitrite-derived ${ }^{\bullet} \mathrm{NO}_{2}$ reacts with LA and DHLA with rate constants of $k=(1.3 \pm 0.1)$ $\times 10^{6}$ and $(2.9 \pm 0.2) \times 10^{7} \mathrm{M}^{-1} \mathrm{~s}^{-1}$, respectively, and with $\mathrm{CO}_{3}^{\bullet-}\left(k=(1.6 \pm 0.02) \times 10^{9}\right.$ and $(1.6 \pm 0.1) \times 10^{8} \mathrm{M}^{-1} \mathrm{~s}^{-1}$, respectively) [86]. Lipoic acid also reacts rapidly with ${ }^{\bullet} \mathrm{OH}$ $\left(4.7 \times 10^{10} \mathrm{M}^{-1} \mathrm{~s}^{-1}\right.$ [87]). Oxidation of LA by these radicals forms the potent one-electron oxidant $\mathrm{LA}^{\bullet+}$ radical cation $\left(E^{0^{\prime}} \mathrm{LA}^{\bullet+} / \mathrm{LA}=1.1 \mathrm{~V}\right)[88]$.

Lipoic acid is both water and fat soluble [84] and increases the oxidation efficiency of peroxynitrite-derived radicals but not the nitration efficiency. The oxidizing radicals react with LA in competition with TyrOH and the resulting LA radical cation can then oxidize TyrOH or its hydrophobic homologue causing its oxidation and dimerization $[67,86]$. In contrast, nitration of BTBE and TyrOH by peroxynitrite is inhibited in the presence of LA and DHLA [86]. Nitration of BTBE is through the one-electron oxidation of BTBE (from ${ }^{\bullet} \mathrm{NO}_{2}$ or $\mathrm{CO}_{3}{ }^{\bullet-}$ ) to a phenoxyl radical which reacts in secondary reactions with - $\mathrm{NO}_{2}$ forming 3- $\mathrm{NO}_{2}$-BTBE. For a bolus addition of peroxynitrite in the presence of LA, all associated radicals are generated simultaneously over a short time (half-life $=1 \mathrm{~s}$ ). ${ }^{\bullet} \mathrm{NO}_{2}$, $\mathrm{CO}_{3}{ }^{\bullet-}$ and ${ }^{\bullet} \mathrm{OH}$ can all react with LA to form LA radical cations which can oxidize BTBE to form BTBE radicals. ${ }^{\bullet} \mathrm{NO}_{2}$ may then not be available to react with BTBE radicals to nitrate them, having already reacted with the excess of LA. In contrast, in steady-state radiolysis studies no change in nitration yields of BTBE were observed in the presence of LA compared to in its absence (L.K. Folkes, personal communication). The presence of LA increased the dimerization yield of BTBE slightly compared to in its absence, which suggests that a higher yield of $\mathrm{BTBE}-\mathrm{TyrO}{ }^{\bullet}$ are formed from reactions with the LA radicals formed from direct reaction of ${ }^{\bullet} \mathrm{NO}_{2}$ with LA. Due to the steady-state formation of ${ }^{\bullet} \mathrm{NO}_{2}$ in radiolysis studies these radicals are still able to react with resulting phenoxyl radicals before they disproportionate or dimerize, simulating a more biologically-relevant condition than fluxes of peroxynitrite-derived radicals arising from the 'bolus' addition of peroxynitrite [7].

\subsection{Reactivity of Hydrogen Sulfide with Peroxynitrite}

Hydrogen sulfide (here the term hydrogen sulfide includes both the undissociated $\left(\mathrm{H}_{2} \mathrm{~S}\right)$ and deprotonated $\left(\mathrm{HS}^{-}\right)$species $\left.(\mathrm{pKa}=6.98)\right)$ [89] is a signaling molecule that can be 
generated endogenously or exogenously administered [90-92]. It participates in several physiological functions including blood vessel relaxation and blood pressure regulation, control of insulin secretion and in the immune system, also presenting anti-apoptosis, antiinflammation, and anti-oxidative stress effects [93]. Peroxynitrite directly reacts with hydrogen sulfide with a rate constant of $(4.8 \pm 1.4) \times 10^{3} \mathrm{M}^{-1} \mathrm{~s}^{-1}\left(\mathrm{pH} 7.4,37^{\circ} \mathrm{C}\right)$. Peroxynitritederived oxidants also react with $\mathrm{H}_{2} \mathrm{~S}$, with one-electron oxidation to a sulfanyl radical $\left(\mathrm{HS}^{\bullet} / \mathrm{S}^{\bullet-}\right)$ which is an oxidizing radical $\left(E^{\circ \prime}\left(\mathrm{HS}^{\bullet}, \mathrm{H}^{+} / \mathrm{H}_{2} \mathrm{~S}\right)=0.91-0.94 \mathrm{~V}\right)$ [94]. Peroxynitrite addition to $\mathrm{H}_{2} \mathrm{~S}$ at low concentrations led to oxygen consumption, which is consistent with sulfanyl radical formation followed by a radical chain reaction. The rate constant of the reaction of $\mathrm{H}_{2} \mathrm{~S}$ with ${ }^{\bullet} \mathrm{NO}_{2}$ and $\mathrm{CO}_{3}{ }^{\bullet-}$ were determined by pulse radiolysis as $(1.2 \pm 0.1) \times 10^{7} \mathrm{M}^{-1} \mathrm{~s}^{-1}$ at $\mathrm{pH} 7.5\left(25^{\circ} \mathrm{C}\right)$ and $(2.0 \pm 0.3) \times 10^{8} \mathrm{M}^{-1} \mathrm{~s}^{-1}$ at $\mathrm{pH} 7$ $\left(20 \pm 2{ }^{\circ} \mathrm{C}\right)$ [94]. Hydrogen sulphide also reacts with several two-electron oxidants such as hydrogen peroxide, hypochlorite, and taurine chloramine, with rate constants of $0.73 \pm 0.03,(8 \pm 3) \times 10^{7}$, and $303 \pm 27 \mathrm{M}^{-1} \mathrm{~s}^{-1}$, respectively $\left(\mathrm{pH} 7.4,37^{\circ} \mathrm{C}\right)$. The protective effects of $\mathrm{H}_{2} \mathrm{~S}$, which are present in tissues at low micromolar or submicromolar concentrations, are probably not completely dependent on direct reactions with oxidants.

\section{Reactivities of Peroxynitrite-Derived Radicals with a Spin Trap and an Iron Chelator}

\subsection{Reactions of $\mathrm{CO}_{3}{ }^{\bullet-}$ and $\mathrm{NO}_{2}$ with $\mathrm{DMPO}$}

'DMPO' (5,5-dimethyl-1-pyrroline-N-oxide) is widely used as a 'spin trap' for radicals involving electron paramagnetic resonance (EPR) detection, since the radical-adducts formed can be long-lived and the signals characteristic of specific radicals. However, for such radical scavengers to be used with confidence, it is important to characterize their reactivities towards key radicals. $\mathrm{CO}_{3}^{\bullet-}$ reacts with DMPO leading to DMPO-OH formation. Pulse radiolysis, EPR, and steady-state competition methods were used to estimate the reactivity of $\mathrm{CO}_{3}{ }^{\bullet-}$ with DMPO [95]. The rate constant of the reaction was $2.5 \times 10^{6} \mathrm{M}^{-1} \mathrm{~s}^{-1}$. Accordingly, DMPO inhibited tyrosine oxidation to diTyr by $\mathrm{CO}_{3}{ }^{\bullet-}$ produced by a Fenton system composed of $\mathrm{Fe}^{(\mathrm{II})}$-DTPA plus $\mathrm{H}_{2} \mathrm{O}_{2}$ in the presence of $\mathrm{HCO}_{3}{ }^{-}$. However, DMPO-OH yields decreased when using this Fenton system plus $\mathrm{HCO}_{3}{ }^{-}$compared with no addition. This is attributed to $\mathrm{CO}_{3}{ }^{\bullet-}$ consumption through reaction with $\mathrm{Fe}$ (II) $-\mathrm{DTPA}$, with a rate constant of $6.1 \times 10^{8} \mathrm{M}^{-1} \mathrm{~s}^{-1}$. The reaction of DMPO and $\mathrm{CO}_{3}{ }^{\bullet-}$ contributes to DMPO-OH formation in cellular systems, as shown using macrophages stimulated to produce peroxynitrite extracellularly in the presence of $\mathrm{HCO}_{3}{ }^{-}$. DMPO reacts with ${ }^{\bullet} \mathrm{NO}_{2}$ yielding an adduct which, according to mass spectrometry analysis, is consistent with the structure DMPO-ONO [96]. Importantly, early spin-trapping experiments characterizing peroxynitrite homolysis found that excess ${ }^{\bullet} \mathrm{NO}_{2}$ destroyed the DMPO-OH signal [97].

\subsection{Reactions of $\mathrm{CO}_{3}^{\bullet-}$ and ${ }^{\bullet} \mathrm{NO}_{2}$ with Desferrioxamine}

As noted earlier, initial interest in free radicals in biology focused on the role of $\mathrm{Fe}^{(\mathrm{II})}$ and Fenton chemistry to generate ${ }^{\bullet} \mathrm{OH}$. A common method to assess such involvement is based on the use of the iron chelator, desferrioxamine [3], but again it is important to assess whether the chelator itself reacts with other radicals (revealed by radiolysis and other kinetic methods) [98]. Desferrioxamine B is a hexadentate trihydroxamic acid siderophore that binds tightly and in a 1:1 ratio with ferric iron $\left(K_{\mathrm{d}} \sim 10^{-31} \mathrm{M}\right)$, which is not able to participate in Haber-Weiss mechanisms [99]. It protects biomolecules from oxidative damage through iron chelation-dependent and -independent mechanisms both in vitro and in vivo [100]. The mechanisms that are iron chelation-independent most frequently involve the reaction of desferrioxamine with oxidizing species such as hydroxyl and superoxide radicals [101,102].

Desferrioxamine inhibits peroxynitrite-mediated oxidations. However, peroxynitrite does not directly react with desferrioxamine [98]. The protective actions of desferrioxamine on peroxynitrite-mediated oxidations depend on its ability to react with peroxynitrite derived radicals, $\bullet \mathrm{OH}_{3} \mathrm{CO}_{3}^{\bullet-}$, and ${ }^{\bullet} \mathrm{NO}_{2}$, forming the relatively-stable desferrioxamine nitroxide radical. Accordingly, desferrioxamine decreases peroxynitrite-dependent tyrosine 
nitration and dimerization in the absence as well as in the presence of $\mathrm{CO}_{2}$. Furthermore, it also decreases peroxynitrite-dependent light emission in carbonate buffer $\mathrm{pH} 10$ (ascribed to $\mathrm{CO}_{3}{ }^{\bullet-}$ formation). Using pulse radiolysis, the rate constants of the reactions of desferrioxamine with $\mathrm{CO}_{3}^{\bullet-}$ and ${ }^{\bullet} \mathrm{NO}_{2}$ were determined as $(1.70 \pm 0.02) \times 10^{9} \mathrm{M}^{-1} \mathrm{~s}^{-1}$ and $(7.6 \pm 0.4) \times 10^{6} \mathrm{M}^{-1} \mathrm{~s}^{-1}$ at $\mathrm{pH} 7.5$, respectively [98]. Furthermore, TyrO ${ }^{\bullet}$ also oxidizes desferrioxamine, with a rate constant of $(6.3 \pm 0.2) \times 10^{6} \mathrm{M}^{-1} \mathrm{~s}^{-1}$ at $\mathrm{pH} 7.4$, while the nitroxide radical of desferrioxamine is able to oxidize thiols such as GSH as well as protein thiols. Thus, the actions of desferrioxamine as an antioxidant can be complex, and kinetic information provided by pulse radiolysis allows to further rationalize its effects.

\section{Conclusions}

A common misconception is that radiation produces such complex fragmentation of molecules that it is of interest only to specialists. In fact, the radiolysis of water is extremely well understood both qualitatively and quantitatively. Many specific free radicals can be generated by exploiting this knowledge and radiolysis can thus be applied to studying diverse reactions of biological interest involving free radicals produced in both normal and pathological conditions in the absence of radiation. Some studies, such as those observing radicals directly in real time following a microsecond pulse of radiation, do require specialist equipment. However, much can be achieved using continuous radiation from sealed or machine sources that are much more accessible. A huge literature concerning rate constants for radical reactions has been built up. We have illustrated here how this experience can be applied in the wider field of free radicals in biology. In particular, following on from the early work of Prütz et al. [26,27], we have focused on how we (and others) have utilized radiation chemistry to study some of the peroxynitrite-derived radical reactions with tyrosine and other biological targets, helping to rationalize its biological effects. In this review, we have addressed here only a part of the extensive work that had focused on oxidative modifications to tyrosine (Figure 3). The reader is referred to an authoritative recent review which illustrates both the importance and complexity of this area [103]. Utilizing multiple techniques, including radiation chemistry, can only add further mechanistic understanding in the areas of redox and free radical biology and biomedicine.

Author Contributions: P.W., L.K.F. and R.R. outlined the structure of the manuscript. P.W. and L.K.F. wrote much of the first version and S.B., M.T. and R.R. completed it. S.B. and R.R. were primarily responsible for making the corrections for the revised version. All authors contributed with the Tables, Figures and References and edited and approved the final version. All authors have read and agreed to the published version of the manuscript.

Funding: This research was supported in part by grants from Universidad de la República (CSIC_2018, Espacio Interdisciplinario_2019). Further support was obtained from Programa de Desarrollo de Ciencias Básicas (PEDECIBA, Uruguay). S.B., M.T. and R.R. are members of the Sistema Nacional de Investigadores (SNI, Uruguay).

Institutional Review Board Statement: Not applicable.

Informed Consent Statement: Not applicable.

Conflicts of Interest: The authors declare no conflict of interest.

\section{References}

1. McCord, J.M.; Fridovich, I. Superoxide dismutase. An enzymic function for erythrocuprein (hemocuprein). J. Biol. Chem. 1969, 244, 6049-6055. [CrossRef]

2. Halliwell, B. Superoxide-dependent formation of hydroxyl radicals in the presence of iron salts. Its role in degradation of hyaluronic acid by a superoxide-generating system. FEBS Lett. 1978, 96, 238-242. [CrossRef]

3. Halliwell, B.; Gutteridge, J.M.C. Free Radicals in Biology and Medicine, 3rd ed.; Oxford University Press: Oxford, UK, 1999.

4. Burkitt, M.J. Chemical, biological and medical controversies surrounding the Fenton reaction. Prog. React. Kinet. Mech. 2003, 38, 75-103. [CrossRef]

5. Wardman, P.; Candeias, L.P. Fenton chemistry: An introduction. Radiat. Res. 1996, 145, 523-531. [CrossRef] [PubMed] 
6. Beckman, J.S.; Beckman, T.W.; Chen, J.; Marshall, P.A.; Freeman, B.A. Apparent hydroxyl radical production by peroxynitrite: Implications for endothelial injury from nitric oxide and superoxide. Proc. Natl. Acad. Sci. USA 1990, 87, 1620-1624. [CrossRef] [PubMed]

7. Ferrer-Sueta, G.; Campolo, N.; Trujillo, M.; Bartesaghi, S.; Carballal, S.; Romero, N.; Alvarez, B.; Radi, R. Biochemistry of Peroxynitrite and Protein Tyrosine Nitration. Chem. Rev. 2018, 118, 1338-1408. [CrossRef]

8. Ischiropoulos, H.; Zhu, L.; Beckman, J.S. Peroxynitrite formation from macrophage-derived nitric oxide. Arch. Biochem. Biophys. 1992, 298, 446-451. [CrossRef]

9. Radi, R.; Beckman, J.S.; Bush, K.M.; Freeman, B.A. Peroxynitrite-induced membrane lipid peroxidation: The cytotoxic potential of superoxide and nitric oxide. Arch. Biochem. Biophys. 1991, 288, 481-487. [CrossRef]

10. Radi, R.; Beckman, J.S.; Bush, K.M.; Freeman, B.A. Peroxynitrite oxidation of sulfhydryls. The cytotoxic potential of superoxide and nitric oxide. J. Biol. Chem. 1991, 266, 4244-4250. [CrossRef]

11. Palmer, R.M.; Ferrige, A.G.; Moncada, S. Nitric oxide release accounts for the biological activity of endothelium-derived relaxing factor. Nature 1987, 327, 524-526. [CrossRef]

12. Radi, R.; Cosgrove, T.P.; Beckman, J.S.; Freeman, B.A. Peroxynitrite-induced luminol chemiluminescence. Biochem. J. 1993, 290, 51-57. [CrossRef] [PubMed]

13. Augusto, O.; Goldstein, S.; Hurst, J.K.; Lind, J.; Lymar, S.V.; Merenyi, G.; Radi, R. Carbon dioxide-catalyzed peroxynitrite reactivity-The resilience of the radical mechanism after two decades of research. Free Radic. Biol. Med. 2019, 135, 210-215. [CrossRef] [PubMed]

14. Radi, R. Nitric oxide, oxidants, and protein tyrosine nitration. Proc. Natl Acad Sci USA 2004, 101, 4003-4008. [CrossRef] [PubMed]

15. Radi, R.; Denicola, A.; Alvarez, B.; Ferrer-Sueta, G.; Rubbo, H. The Biological Chemistry of Peroxynitrite. In Nitric Oxide Biology and Pathobiology; Ignarro, L.J., Ed.; Academic Press: San Diego, CA, USA, 2000; pp. 57-82.

16. Fleming, A.M.; Burrows, C.J. Iron Fenton oxidation of 2 '-deoxyguanosine in physiological bicarbonate buffer yields products consistent with the reactive oxygen species carbonate radical anion not the hydroxyl radical. Chem. Commun. 2020, 56, 9779-9782. [CrossRef]

17. Patra, S.G.; Mizrahi, A.; Meyerstein, D. The Role of Carbonate in Catalytic Oxidations. Acc. Chem Res. 2020, 53, 2189-2200. [CrossRef]

18. Hawkins, C.L.; Davies, M.J. Generation and propagation of radical reactions on proteins. Biochim. Biophys. Acta 2001, 1504, 196-219. [CrossRef]

19. Houée-Levin, C.; Bobrowski, K. The use of the methods of radiolysis to explore the mechanisms of free radical modifications in proteins. J. Proteom. 2013, 92, 51-62. [CrossRef]

20. Kobayashi, K. Pulse Radiolysis Studies for Mechanism in Biochemical Redox Reactions. Chem. Rev. 2019, 119, 4413-4462. [CrossRef]

21. Schoneich, C. Radical rearrangement and transfer reactions in proteins. Essays Biochem. 2020, 64, 87-96. [CrossRef]

22. Adams, G.E.; Michael, B.D. Pulse radiolysis of benzoquinone and hydroquinone. Semiquinone formation by water elimination from trihydroxy-ciclohexadienyl radicals. Trans. Faraday Soc. 1967, 63, 1171-1180. [CrossRef]

23. Land, E.J.; Ebert, M. Pulse radiolysis studies in aqueous phenol. Trans. Faraday Soc. 1967, 63, 1181-1190. [CrossRef]

24. Adams, G.E.; Aldrich, J.E.; Bisby, R.H.; Cundall, R.B.; Redpath, J.L.; Willson, R.L. Selective free radical reactions with proteins and enzymes: Reactions of inorganic radical anions with amino acids. Radiat Res. 1972, 49, 278-289. [CrossRef] [PubMed]

25. Adams, G.E.; Bisby, R.H.; Cundall, R.B.; Redpath, J.L.; Willson, R.L. Selective free radical reactions with proteins and enzymes: The inactivation of ribonuclease. Radiat. Res. 1972, 49, 290-299. [CrossRef] [PubMed]

26. Prutz, W.A.; Monig, H.; Butler, J.; Land, E.J. Reactions of nitrogen dioxide in aqueous model systems: Oxidation of tyrosine units in peptides and proteins. Arch. Biochem. Biophys. 1985, 243, 125-134. [CrossRef]

27. Prutz, W.A.; Butler, J.; Land, E.J.; Swallow, A.J. Direct demonstration of electron transfer between tryptophan and tyrosine in proteins. Biochem. Biophys. Res. Commun. 1980, 96, 408-414. [CrossRef]

28. Bobrowski, K.; Wierzchowski, K.L.; Holcman, J.; Ciurak, M. Pulse radiolysis studies of intramolecular electron transfer in model peptides and proteins. IV. Met/S:.Br->Tyr/O. radical transformation in aqueous solution of H-Tyr-(Pro)n-Met-OH peptides. Int. J. Radiat. Biol. 1992, 62, 507-516. [CrossRef]

29. Dixon, W.T.; Murphy, D. Determination of acid dissociation constants of some phenol radical cations. J. Chem. Soc. Faraday Trans. 2 1978, 74, 432-439. [CrossRef]

30. Czapski, G.; Lymar, S.V.; Schwarz, H.A. Acidity of the carbonate radical. J. Phys. Chem. 1999, 103, 3447-3450. [CrossRef]

31. Posener, M.L.; Adams, G.E.; Wardman, P.; Cundall, R.B. Mechanisms of tryptophan oxidations by some inorganic radical-anions: A pulse radiolysis study. J. Chem. Soc. Faraday Trans. 1 1976, 72, 2231-2239. [CrossRef]

32. Mozumder, A. Fundamentals of Radiation Chemistry; Academic Press: San Diego, CA, USA, 1999.

33. Buxton, G.V. Radiation chemistry of the liquid state: (I) Water and homogeneous aqueous solutions. In Radiation Chemistry. Principles and Applications; Farhataziz, R.M.A.J., Ed.; VCH Publisher: New York, NY, USA, 1987; pp. 321-349.

34. Buxton, G.V.; Greenstock, C.L.; Helman, W.P.; Ross, A.B. Critical review of rate constants for reactions of hydrated electrons, hydrogen atoms and hydroxyl radicals (.OH/ .O-) in aqueous solution. J. Phys. Chem. Ref. Data 1988, 17, 513-886. [CrossRef]

35. Madden, K.P.; Mezyk, S.P. Critical review of aqueous solution reaction rate constants for hydrogen atoms. J. Phys. Chem. Ref. Data. 2011, 40, 023103. [CrossRef] 
36. Bielski, B.H.J.; Cabelli, D.E.; Arudi, R.L. Reactivity of HO2/O2- radicals in aqueous solution. J. Phys. Chem. Ref. Data. 1985, 14, 1041-1100. [CrossRef]

37. Neta, P.; Huie, R.E.; Ross, A.B. Rate constants for reactions of peroxyl radicals in fluid solutions. J. Phys. Chem. Ref. Data. 1990, 19, 413-513. [CrossRef]

38. Neta, P.; Grodkowski, J. Rate constants for reactions of phenoxyl radicals in solution. J. Phys. Chem. Ref. Data. 2005, 34, 109-199. [CrossRef]

39. Neta, P.; Huie, R.E.; Ross, A.B. Rate constants for reactions of inorganic radicals in aqueous solution. J. Phys. Chem. Ref. Data. 1988, 17, 1027-1284. [CrossRef]

40. Neta, P.; Grodkowski, J.; Ross, A.B. Rate constants for reactions of aliphatic carbon-centered radicals in aqueous solution. J. Phys. Chem. Ref. Data. 1996, 25, 709-1050. [CrossRef]

41. Buxton, G.V.; Mulazzani, Q.G.; Ross, A.B. Critical review of rate constants for reactions of transients from metal ions and metal complexes in aqueous solution. J. Phys. Chem. Ref. Data. 1985, 24, 1055-1349. [CrossRef]

42. Marcus, R.A. Electron transfer reactions in chemistry. Theory and experiment. Rev. Mod. Phys. 1993, 65, 599-610. [CrossRef]

43. Folkes, L.K.; Candeias, L.P. Interpretation of the reactivity of peroxidase compounds I and II with phenols by the Marcus equation. FEBS Lett 1997, 412, 305-308. [CrossRef]

44. Silverstein, T.P. Marcus Theory: Thermodynamics CAN control the kinetics of electron transfer reactions. J. Chem. Educ. 2012, 89, 1159-1167. [CrossRef]

45. Armstrong, D.A.; Huie, R.E.; Koppenol, W.H.; Lymar, S.V.; Merenyi, G.; Neta, P.; Ruscica, B.; Stanburyd, D.M.; Steenken, S.; Wardman, P. Standard electrode potentials involving radicals in aqueous solution: Inorganic radicals (IUPAC Technical Report) Pure Appl. Chem. 2015, 87, 1139-1150. [CrossRef]

46. Wardman, P. Reduction potentials of one-electron couples involving free radicals in aqueous solution. J. Phys. Chem. Ref. Data. 1989, 18, 1637-1755. [CrossRef]

47. Madej, E.; Wardman, P. The oxidizing power of the glutathione thiyl radical as measured by its electrode potential at physiological pH. Arch. Biochem. Biophys. 2007, 462, 94-102. [CrossRef] [PubMed]

48. Augusto, O.; Bonini, M.G.; Amanso, A.M.; Linares, E.; Santos, C.C.; De Menezes, S.L. Nitrogen dioxide and carbonate radical anion: Two emerging radicals in biology. Free Radic. Biol. Med. 2002, 32, 841-859. [CrossRef]

49. Gunther, M.R.; Hsi, L.C.; Curtis, J.F.; Gierse, J.K.; Marnett, L.J.; Eling, T.E.; Mason, R.P. Nitric oxide trapping of the tyrosyl radical of prostaglandin $\mathrm{H}$ synthase-2 leads to tyrosine iminoxyl radical and nitrotyrosine formation. J. Biol. Chem. 1997, 272, 17086-17090. [CrossRef]

50. Lepoivre, M.; Flaman, J.M.; Henry, Y. Early loss of the tyrosyl radical in ribonucleotide reductase of adenocarcinoma cells producing nitric oxide. J. Biol. Chem. 1992, 267, 22994-23000. [CrossRef]

51. Heinecke, J.W.; Li, W.; Francis, G.A.; Goldstein, J.A. Tyrosyl radical generated by myeloperoxidase catalyzes the oxidative cross-linking of proteins. J. Clin. Investig. 1993, 91, 2866-2872. [CrossRef] [PubMed]

52. Alvarez, B.; Ferrer-Sueta, G.; Freeman, B.A.; Radi, R. Kinetics of peroxynitrite reaction with amino acids and human serum albumin. J. Biol. Chem. 1999, 274, 842-848. [CrossRef]

53. Folkes, L.K.; Trujillo, M.; Bartesaghi, S.; Radi, R.; Wardman, P. Kinetics of reduction of tyrosine phenoxyl radicals by glutathione Arch. Biochem. Biophys. 2011, 506, 242-249. [CrossRef]

54. Hunter, E.P.; Desrosiers, M.F.; Simic, M.G. The effect of oxygen, antioxidants, and superoxide radical on tyrosine phenoxyl radical dimerization. Free Radic Biol. Med. 1989, 6, 581-585. [CrossRef]

55. Cuddihy, S.L.; Parker, A.; Harwood, D.T.; Vissers, M.C.; Winterbourn, C.C. Ascorbate interacts with reduced glutathione to scavenge phenoxyl radicals in HL60 cells. Free Radic. Biol. Med. 2008, 44, 1637-1644. [CrossRef] [PubMed]

56. Jacob, J.S.; Cistola, D.P.; Hsu, F.F.; Muzaffar, S.; Mueller, D.M.; Hazen, S.L.; Heinecke, J.W. Human phagocytes employ the myeloperoxidase-hydrogen peroxide system to synthesize dityrosine, trityrosine, pulcherosine, and isodityrosine by a tyrosyl radical-dependent pathway. J. Biol. Chem. 1996, 271, 19950-19956. [CrossRef] [PubMed]

57. Skaff, O.; Jolliffe, K.A.; Hutton, C.A. Synthesis of the side chain cross-linked tyrosine oligomers dityrosine, trityrosine and pulcherosine. J. Org. Chem. 2005, 70, 7353-7363. [CrossRef]

58. Bartesaghi, S.; Ferrer-Sueta, G.; Peluffo, G.; Valez, V.; Zhang, H.; Kalyanaraman, B.; Radi, R. Protein tyrosine nitration in hydrophilic and hydrophobic environments. Amino Acids 2007, 32, 501-515. [CrossRef] [PubMed]

59. Bartesaghi, S.; Radi, R. Fundamentals on the biochemistry of peroxynitrite and protein tyrosine nitration. Redox Biol. 2018, 14, 618-625. [CrossRef] [PubMed]

60. Campolo, N.; Issoglio, F.M.; Estrin, D.A.; Bartesaghi, S.; Radi, R. 3-Nitrotyrosine and related derivatives in proteins: Precursors, radical intermediates and impact in function. Essays Biochem. 2020, 64, 111-133. [CrossRef] [PubMed]

61. Winterbourn, C.C.; Parsons-Mair, H.N.; Gebicki, S.; Gebicki, J.M.; Davies, M.J. Requirements for superoxide-dependent tyrosine hydroperoxide formation in peptides. Biochem. J. 2004, 381, 241-248. [CrossRef]

62. Jin, F.; Leitich, J.; von Sonntag, C. The superoxide radical reacts with tyrosine-derived phenoxyl radicals by addition rather than by electron transfer. Perkin Trans. 2 1993, 2, 1583-1588. [CrossRef]

63. Das, A.B.; Nauser, T.; Koppenol, W.H.; Kettle, A.J.; Winterbourn, C.C.; Nagy, P. Rapid reaction of superoxide with insulin-tyrosyl radicals to generate a hydroperoxide with subsequent glutathione addition. Free Radic. Biol. Med. 2014, 70, 86-95. [CrossRef] 
64. Nagy, P.; Kettle, A.J.; Winterbourn, C.C. Neutrophil-mediated oxidation of enkephalins via myeloperoxidase-dependent addition of superoxide. Free Radic. Biol. Med. 2010, 49, 792-799. [CrossRef]

65. Nagy, P.; Lechte, T.P.; Das, A.B.; Winterbourn, C.C. Conjugation of glutathione to oxidized tyrosine residues in peptides and proteins. J. Biol. Chem. 2012, 287, 26068-26076. [CrossRef]

66. Zhang, H.; Joseph, J.; Feix, J.; Hogg, N.; Kalyanaraman, B. Nitration and oxidation of a hydrophobic tyrosine probe by peroxynitrite in membranes: Comparison with nitration and oxidation of tyrosine by peroxynitrite in aqueous solution. Biochemistry 2001, 40, 7675-7686. [CrossRef] [PubMed]

67. Bartesaghi, S.; Valez, V.; Trujillo, M.; Peluffo, G.; Romero, N.; Zhang, H.; Kalyanaraman, B.; Radi, R. Mechanistic studies of peroxynitrite-mediated tyrosine nitration in membranes using the hydrophobic probe N-t-BOC-L-tyrosine tert-butyl ester. Biochemistry 2006, 45, 6813-6825. [CrossRef] [PubMed]

68. Batthyany, C.; Bartesaghi, S.; Mastrogiovanni, M.; Lima, A.; Demicheli, V.; Radi, R. Tyrosine-Nitrated Proteins: Proteomic and Bioanalytical Aspects. Antioxid. Redox Signal. 2017, 26, 313-328. [CrossRef] [PubMed]

69. Bartesaghi, S.; Herrera, D.; Martinez, D.M.; Petruk, A.; Demicheli, V.; Trujillo, M.; Marti, M.A.; Estrin, D.A.; Radi, R. Tyrosine oxidation and nitration in transmembrane peptides is connected to lipid peroxidation. Arch. Biochem. Biophys. 2017, 622, 9-25. [CrossRef]

70. Bartesaghi, S.; Wenzel, J.; Trujillo, M.; Lopez, M.; Joseph, J.; Kalyanaraman, B.; Radi, R. Lipid peroxyl radicals mediate tyrosine dimerization and nitration in membranes. Chem. Res. Toxicol. 2010, 23, 821-835. [CrossRef] [PubMed]

71. Romero, N.; Peluffo, G.; Bartesaghi, S.; Zhang, H.; Joseph, J.; Kalyanaraman, B.; Radi, R. Incorporation of the hydrophobic probe $\mathrm{N}-\mathrm{t}$-BOC-L-tyrosine tert-butyl ester to red blood cell membranes to study peroxynitrite-dependent reactions. Chem. Res. Toxicol. 2007, 20, 1638-1648. [CrossRef]

72. Zhang, H.; Bhargava, K.; Keszler, A.; Feix, J.; Hogg, N.; Joseph, J.; Kalyanaraman, B. Transmembrane nitration of hydrophobic tyrosyl peptides. Localization, characterization, mechanism of nitration, and biological implications. J. Biol. Chem. 2003, 278, 8969-8978. [CrossRef]

73. Folkes, L.K.; Bartesaghi, S.; Trujillo, M.; Radi, R.; Wardman, P. Kinetics of oxidation of tyrosine by a model alkoxyl radical. Free Radic. Res. 2012, 46, 1150-1156. [CrossRef]

74. Erben-Russ, M.; Michel, C.; Bors, W.; Saran, M. Absolute rate constants of alkoxyl radical reactions in aqueous solution. J. Phys. Chem. 1987, 91, 2362-2365. [CrossRef]

75. Wilcox, A.L.; Marnett, L.J. Polyunsaturated fatty acid alkoxyl radicals exist as carbon-centered epoxyallylic radicals: A key step in hydroperoxide-amplified lipid peroxidation. Chem. Res. Toxicol. 1993, 6, 413-416. [CrossRef]

76. Folkes, L.K.; Bartesaghi, S.; Trujillo, M.; Wardman, P.; Radi, R. The effects of nitric oxide or oxygen on the stable products formed from the tyrosine phenoxyl radical. Free Radic Res. 2021, 55, 141-153. [CrossRef] [PubMed]

77. Eiserich, J.P.; Butler, J.; van der Vliet, A.; Cross, C.E.; Halliwell, B. Nitric oxide rapidly scavenges tyrosine and tryptophan radicals. Biochem. J. 1995, 310, 745-749. [CrossRef]

78. Lynn, K.R.; Purdie, J.W. Some pulse and gamma radiolysis studies of tyrosine and its glycyl peptides. Int. J. Radiat. Phys. Chem. 1976, 8, 685-689. [CrossRef]

79. Solar, S.; Solar, W.; Getoff, N. Reactivity of $\mathrm{OH}$ with tyrosine in aqueous solution studied by pulse radiolysis. J. Phys. Chem. 1984, 88, 2091-2095. [CrossRef]

80. Cudina, I.; Josimovic, J. The effect of oxygen on the radiolysis of tyrosine in aqueous solutions. Radiat. Res. 1987, 109, 206-215. [CrossRef] [PubMed]

81. Mvula, E.; Schuchmann, M.N.; Sonntag, C.V. Reactions of phenol-OH-adduct radicals. Phenoxyl radical formation by water elimination vs. oxidation by dioxygen. J. Chem. Soc. Perkin Trans. 2001, 2, 264-268. [CrossRef]

82. Pedron, F.N.; Bartesaghi, S.; Estrin, D.A.; Radi, R.; Zeida, A. A computational investigation of the reactions of tyrosyl, tryptophanyl, and cysteinyl radicals with nitric oxide and molecular oxygen. Free Radic. Res. 2019, 53, 18-25. [CrossRef] [PubMed]

83. Folkes, L.K. The Role of Nitric Oxide as a Hypoxic Cell Radiosensitizer. Doctoral Dissertation, Linacre College, University of Oxford, Oxford, UK, 2013.

84. Packer, L.; Witt, E.H.; Tritschler, H.J. alpha-Lipoic acid as a biological antioxidant. Free Radic. Biol. Med. 1995, 19, 227-250. [CrossRef]

85. Trujillo, M.; Radi, R. Peroxynitrite reaction with the reduced and the oxidized forms of lipoic acid: New insights into the reaction of peroxynitrite with thiols. Arch. Biochem. Biophys. 2002, 397, 91-98. [CrossRef]

86. Trujillo, M.; Folkes, L.; Bartesaghi, S.; Kalyanaraman, B.; Wardman, P.; Radi, R. Peroxynitrite-derived carbonate and nitrogen dioxide radicals readily react with lipoic and dihydrolipoic acid. Free Radic. Biol. Med. 2005, 39, 279-288. [CrossRef] [PubMed]

87. Scott, B.C.; Aruoma, O.I.; Evans, P.J.; O’Neill, C.; Van der Vliet, A.; Cross, C.E.; Tritschler, H.; Halliwell, B. Lipoic and dihydrolipoic acids as antioxidants. A critical evaluation. Free Radic. Res. 1994, 20, 119-133. [CrossRef] [PubMed]

88. Lu, C.; Liu, Y. Interactions of lipoic acid radical cations with vitamins $\mathrm{C}$ and $\mathrm{E}$ analogue and hydroxycinnamic acid derivatives. Arch. Biochem. Biophys. 2002, 406, 78-84. [CrossRef]

89. Benchoam, D.; Cuevasanta, E.; Moller, M.N.; Alvarez, B. Hydrogen Sulfide and Persulfides Oxidation by Biologically Relevant Oxidizing Species. Antioxidants 2019, 8, 48. [CrossRef]

90. Filipovic, M.R.; Zivanovic, J.; Alvarez, B.; Banerjee, R. Chemical Biology of H2S Signaling through Persulfidation. Chem. Rev. 2018, 118, 1253-1337. [CrossRef] [PubMed] 
91. Levinn, C.M.; Cerda, M.M.; Pluth, M.D. Activatable Small-Molecule Hydrogen Sulfide Donors. Antioxid. Redox Signal. 2020, 32, 96-109. [CrossRef]

92. Myszkowska, J.; Derevenkov, I.; Makarov, S.V.; Spiekerkoetter, U.; Hannibal, L. Biosynthesis, Quantification and Genetic Diseases of the Smallest Signaling Thiol Metabolite: Hydrogen Sulfide. Antioxidants 2021, 10, 1065. [CrossRef]

93. Beltowski, J. Synthesis, Metabolism, and Signaling Mechanisms of Hydrogen Sulfide: An Overview. Methods Mol. Biol. 2019, 2007, 1-8. [CrossRef]

94. Das, T.N.; Huie, R.E.; Neta, P.; Padmaja, S. Reduction potential of the sulhydryl radical: Pulse radiolysis and laser flash photolysis studies on the formation and reactions of SH and HSSH-In aqueous solution. J. Phys. Chem. A 1999, 103, 5221-5226. [CrossRef]

95. Alvarez, M.N.; Peluffo, G.; Folkes, L.; Wardman, P.; Radi, R. Reaction of the carbonate radical with the spin-trap 5,5-dimethyl-1pyrroline-N-oxide in chemical and cellular systems: Pulse radiolysis, electron paramagnetic resonance, and kinetic-competition studies. Free Radic. Biol. Med. 2007, 43, 1523-1533. [CrossRef]

96. Nash, K.M.; Rockenbauer, A.; Villamena, F.A. Reactive nitrogen species reactivities with nitrones: Theoretical and experimental studies. Chem. Res. Toxicol. 2012, 25, 1581-1597. [CrossRef] [PubMed]

97. Augusto, O.; Gatti, R.M.; Radi, R. Spin-trapping studies of peroxynitrite decomposition and of 3-morpholinosydnonimine N-ethylcarbamide autooxidation: Direct evidence for metal-independent formation of free radical intermediates. Arch. Biochem. Biophys. 1994, 310, 118-125. [CrossRef]

98. Bartesaghi, S.; Trujillo, M.; Denicola, A.; Folkes, L.; Wardman, P.; Radi, R. Reactions of desferrioxamine with peroxynitrite-derived carbonate and nitrogen dioxide radicals. Free Radic. Biol. Med. 2004, 36, 471-483. [CrossRef]

99. Denicola, A.; Souza, J.M.; Gatti, R.M.; Augusto, O.; Radi, R. Desferrioxamine inhibition of the hydroxyl radical-like reactivity of peroxynitrite: Role of the hydroxamic groups. Free Radic. Biol. Med. 1995, 19, 11-19. [CrossRef]

100. Reeder, B.J.; Hider, R.C.; Wilson, M.T. Iron chelators can protect against oxidative stress through ferryl heme reduction. Free Radic. Biol. Med. 2008, 44, 264-273. [CrossRef] [PubMed]

101. Davies, M.J.; Donkor, R.; Dunster, C.A.; Gee, C.A.; Jonas, S.; Willson, R.L. Desferrioxamine (Desferal) and superoxide free radicals. Formation of an enzyme-damaging nitroxide. Biochem. J. 1987, 246, 725-729. [CrossRef]

102. Hoe, S.; Rowley, D.A.; Halliwell, B. Reactions of ferrioxamine and desferrioxamine with the hydroxyl radical. Chem. Biol. Interact. 1982, 41, 75-81. [CrossRef]

103. Houée-Levin, C.; Bobrowski, K.; Horakova, L.; Karademir, B.; Schoneich, C.; Davies, M.J.; Spickett, C.M. Exploring oxidative modifications of tyrosine: An update on mechanisms of formation, advances in analyisis and biological consequences. Free Radic. Res. 2015, 49, 347-373. [CrossRef] 